
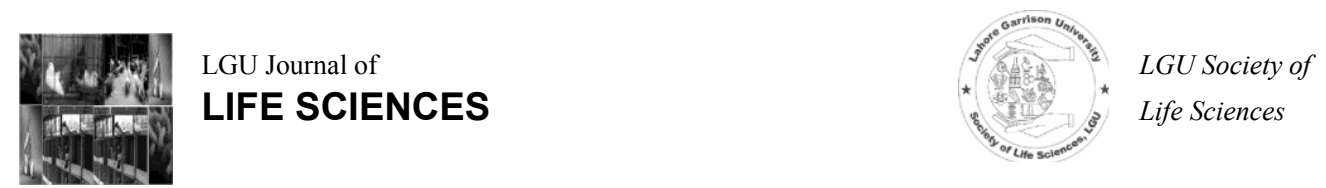

\title{
Development and Quality Evaluation of Nutritious and Healthy Biscuits for Dogs
}

Naseem Zahra*, Syed Hussain Abidi, Qurat-ul-Ain Syed, Muhammad Khalid Saeed Food and Biotechnology Research Centre, Pakistan Council of Scientific and Industrial Research Laboratories Complex, Ferozepur Road, Lahore-54600, Pakistan

* Corresponding Author's Email: naseem.zahra1981@gmail.com

ABSTRACT: Pet food awareness among people is increasing day by day due to humanization trends towards pets. The pet owners are searching for various quality pet foods having different tastes. Therefore, there is an increase demand of premium products i.e. organic, raw and natural pet foods which are giving lots of choices for pet owners. The present study entails the preparation of dog biscuits by using cheap and organic sources. Orange, apple and banana peels were used in the preparation of dog biscuits in order to utilize fruits wastes. Nutritional, heavy metals and aflatoxins analyses was done to evaluate useful aspects of biscuits for dogs. Aflatoxins were absent in biscuits and heavy metals were also within permissible levels showing harmlessness of biscuits for pet dog. The biscuits were offered to pet dogs for sensory evaluation and were found acceptable. The results from nutritional analysis showed that the prepared biscuits for dog are a nutritive food having enough high calories of $407.55 \mathrm{Kcal} / 100 \mathrm{~g}$ in order to fulfill dietary requirements of dogs. It was concluded that prepared biscuits for dogs were nutritionally fit for dog's health.

Keywords: Nutritional analysis, Aflatoxins, Heavy metals, dogs, biscuits

\section{INTRODUCTION}

$\mathbf{P}_{\text {et dogs are being treated }}$ everywhere in the world as "family members" now-a-days. Pet food industry is multimillion businesses as the commercial dog foods are too costly to provide to pet dogs by common people (Deuri et al., 2019). There are so many commercial dog foods available in market with respect to dog age, breed type and life stages. In Pakistan the trend of setting pet food industries is on the rise as people have now became aware.

Dog biscuit is taken as full diet supplement for pet dogs and other pet animals. Dog biscuits are likely as hard and dry entity. A proper diet and its nutritional aspects are very important for dog's good health. It is much needed that biscuits have proper amount of nutrients and other ingredients (Akinrinmade and 
Akinrinde, 2011). Common dog biscuits typically contain between about $60-70 \%$ wheat flour (Scaglione and Gellman, 1988). Normally dog biscuits are composed of food grade cellulose, salt, best binder to hold the whole matrix and flavors and taste enhancers.

The dog biscuits are prepared by ingredients of low calories so that they can be consumed by a dog in large amount without creating obesity problem (Andersen and Harpe, 1990). Pet manufacturer have art to mix different blends in appropriate proportions of meat cuts, vegetables, cereals, fish, minerals and vitamins. The nutritionally balanced pet food is prepared by pet food manufactures so that pet can enjoy delicious balanced diet. There are so many choices for pet owners to prepare pet food of great quality by mixing raw materials for wet and dry formulations for pet treats.

Dog biscuits are ready to eat pet food product which are conveniently prepared and are inexpensive. The dietary principles and digestives requirements are kept in mind while selecting ingredients and preparing biscuits (Kulkarni, 1997). Wheat flour, sugar, salt, baking powder, milk and different flavors are main ingredients for biscuits making (Obasi et al., 2012). Peels powders play an important role in enhancing nutritional aspects. The apple peels help manage oxidative stress and maintain inflammation within the normal range. Banana peels are also useful from nutrition point of view as they contain 6-
$9 \%$ protein (dry matter) and $20-30 \%$ fiber. Similarly, orange peels are the source of vitamins $\mathrm{A}$ and $\mathrm{C}$ and contain antioxidants which are helpful in boosting immunity. These are useful for medicinal purpose as well e.g. in flu, colds and infections (Wolfe et al., 2003; Kalpna and Mital, 2011).

Different manufacturers of numerous pet foods are preparing complementary; dry snacks, treats or raw and wet foods for dogs (Beynen, 2020). There is lack of study regarding pet food and this study is the first step towards developing and evaluating dog food. This study was carried out with the objectives of formulating an edible dogfood in biscuits form using locally available ingredients in Pakistan at lower price level, which confirm the main nutritional requirements. It is designed as such that all nutritional and energy requirements are kept in mind and the use of peels of different fruits and meat in preparation of biscuits is worth mentioning aspect in biscuits composition in order to add different important nutrients.

\section{MATERIALS AND METHODS}

Fresh fruits (Orange, apple and banana) were purchased from local market of Lahore. The fruits were peeled off. The peels were taken and washed carefully with water to remove dust and other particles. All the peels were then dried with neat cloth. The dried peels were then kept in drying oven for 12 hours at $70{ }^{\circ} \mathrm{C}$. The dried peels were 
grinded to fine powder. The list of ingredients have shown in Table 1.

Table 1: List of ingredients for the preparation of biscuits for dogs

\begin{tabular}{lll}
\hline Sr. No. & Name of Ingredients & Percentage (\%) \\
\hline $\mathbf{1}$ & All purpose flour & 32 \\
$\mathbf{2}$ & Wheat Flour & 15 \\
$\mathbf{3}$ & Baking powder & 0.4 \\
$\mathbf{4}$ & Butter & 5 \\
$\mathbf{5}$ & Sugar & 20 \\
$\mathbf{6}$ & Milk & 7 \\
$\mathbf{7}$ & Orange peel powder & 2 \\
$\mathbf{8}$ & Apple peel powder & 2 \\
$\mathbf{9}$ & Banana peel powder & 2 \\
$\mathbf{1 0}$ & Salt & 1 \\
$\mathbf{1 1}$ & Meat pieces & 3 \\
$\mathbf{1 2}$ & Vanilla Essence & 0.2 \\
$\mathbf{1 3}$ & Cocoa Powder & 0.4 \\
$\mathbf{1 4}$ & Egg & 7.5 \\
$\mathbf{1 5}$ & Oil & 2.5 \\
\hline
\end{tabular}

Eggs, milk and sugar were firstly well batted and then all the ingredients were well mixed to get fine dough. The dough was rolled out on a thick sheet and was cut with a cutter in different desired shapes. The unused dough was again pressed and same procedure of rolling was repeated and biscuits were cut in different shapes. The tray was covered greased by oil and covered with butter paper which again was greased by oil and biscuits were placed for baking in preheated oven for 10 minutes at $180^{\circ} \mathrm{C}$ till the biscuits became golden brown.

\section{Evaluation of Physico-Chemical Parameters}

\section{1. pH Determination}

$5 \%$ solution of the biscuits was prepared using water and $\mathrm{pH}$ was checked by $\mathrm{pH}$ meter.

\section{Nutritional Analysis}

The nutritional composition of the dog biscuits was determined and all the experiments were carried out in the laboratories of Food Department, PCSIR Laboratories Complex Lahore, Pakistan. The dog biscuits were grinded to fine powder and packed in air-tight polythene bag and were labeled for nutritional analysis. The percentages of moisture content, crude fire, ash and crude protein in the dog biscuits were determined by using official methods (AOAC, 1990). 5g of biscuits in powder form were weighed and placed in hot air oven at $130^{\circ} \mathrm{C}$ to a constant or at equilibrium weight. After three hours, the difference in weight was recorded as the moisture content and percentage was calculated. $0.5 \mathrm{~g}$ of the powdered biscuit sample was weighed and placed in a pre-weighed china 
crucible and ignited in an ash furnace maintained at $550^{\circ} \mathrm{C}$ till the fine ash was obtained. The percentage ash was calculated. The nitrogen contents were determined by using micro-Kjeldahl method and then multiplied by 6.25 to estimate the crude protein contents in biscuit samples. Percentage of carbohydrate was also calculated by the difference as depicted (AOAC, 1990).

\section{Determination of Heavy Metal}

\section{Contamination}

The solution was prepared by taking $1 \mathrm{~g}$ ash. The sample in crucible was taken, ignited and then placed in furnace. The obtained ash was dissolved in distilled water by adding nitric acid then filtered to make volume $100 \mathrm{ml}$ using distilled water. Different metals (Lead, Cadmium, Copper, Nickel, Cobalt, Zinc and Mercury) were then measured by Atomic Absorption Spectrophotometer alongwith their respective standards (Bhowmik et al., 2008). Arsenic was determined by using Inductively Coupled Plasma.

\section{Aflatoxin Determination}

Aflatoxins in biscuits were determined by using thin layer chromatographic technique (Nisa et al.,
2012). Aflatoxins were analyzed (Begum, 1985) in prepared biscuits for dog. 50g of biscuits in powdered form were taken and $250 \mathrm{ml}$ chloroform was added and then shaken for 30 minutes. Then $50 \mathrm{ml}$ of sample solution was taken and dried on water bath. Volume was prepared and spotting was done on TLC plate as in depicted method (Romer, 1976). The different concentrations of standard were compared with the sample extract for the aflatoxin determination (AOAC, 2005). Total aflatoxins (AFB1+AFB2+AFG1+AFG2) were determined by given formula (Zahra et al., 2020).

Aflatoxin B1 $(\mu \mathrm{g} / \mathrm{kg})=\frac{\mathrm{S} \times \mathrm{Yx} \mathrm{V}}{\mathrm{W} \times \mathrm{Z}}$

\section{RESULTS AND DISCUSSION}

The prepared dog biscuits were analyzed for its physicochemical and nutritional aspects. Presence of heavy metals in biscuits may have venomous effects on human health. So, the determination of heavy metals in biscuits was necessary. Analysis of heavy metals includes lead, cadmium, copper, nickel, cobalt, zinc, arsenic and mercury. The results are given in Table 2. 
Table 2: Results of Physico-Chemical tests of prepared dog biscuits

\begin{tabular}{rll}
\hline Sr. No. & Parameter & Values \\
\hline 1. & $\mathrm{pH}$ & $6.78 \pm 0.05$ \\
2. & Lead & $\mathrm{ND}$ \\
3. & Cadmium & $\mathrm{ND}$ \\
4. & Copper & $\mathrm{ND}$ \\
5. Nickel & $\mathrm{ND}$ \\
6. Cobalt & $\mathrm{ND}$ \\
7. Zinc & $0.1 \pm 0.01 \mathrm{ppb}$ \\
8. Arsenic & $0.2 \pm 0.01 \mathrm{ppb}$ \\
9. Mercury & $\mathrm{ND}$ \\
\hline
\end{tabular}

$* \mathrm{ND}=$ Not Detected

The nutritional analysis results showed that the prepared dog biscuits may be considered as a nutritive and potential food entity as having high calories of $407.55 \pm 0.1 \mathrm{Kcal} / 100 \mathrm{~g}$ in order to fulfill the dietary requirements.

Table 3: Results of Nutritional Analysis of prepared dog biscuits

\begin{tabular}{cll}
\hline Sr. No. & Parameter & Values \\
\hline 1. & Moisture (\%) & $7.70 \pm 0.05$ \\
2. & Ash (\%) & $0.95 \pm 0.02$ \\
3. & Protein $(\%)$ & $8.18 \pm 0.05$ \\
4. & Fat $(\%)$ & $8.67 \pm 0.05$ \\
5. & Fiber (\%) & $0.30 \pm 0.01$ \\
6. & Carbohydrates $(\%)$ & $74.20 \pm 0.1$ \\
7. & Energy (Kcal/ $100 \mathrm{~g})$ & $407.55 \pm 0.1$ \\
\hline
\end{tabular}

Aflatoxins are the fungal prepared biscuits were found safe for dog metabolites which are declared as consumption as there was no carcinogenic species by International contamination of aflatoxins. It was Agency of Cancer on Research. These depicted by all parameters that dog may affect biscuits quality to greater biscuits are secure for dog's health (Table extent and also human health may affect 4).

(Zahra et al., 2015). In this study,

\begin{tabular}{cll}
\multicolumn{2}{c}{ Table 4. } & Aflatoxin Analysis of Dog Food Biscuits \\
\hline Sr. No. & Aflatoxins & Concentration (ppb) \\
\hline 1. & B1 & Not Detected \\
2. & B2 & Not Detected \\
3. & G1 & Not Detected \\
4. & G2 & Not Detected
\end{tabular}

From this study it was obtained distinctively provide good results for dog that the prepared biscuits are novel and consumption with good calories. 


\section{CONCLUSION}

The day by day increasing reliance on dogs for sanctuary and companion is thought to be responsible for the remarkable growth of the pet food industry, with analogous amplifying of demand for dog food by pet owners and dog breeders. The present work is focused on preparation of dog biscuits with best nutritional values. The nutritional analysis showed its efficacy for dogs use. No harmful metal was detected in prepared biscuits for dogs. To the best of our acquaintance, information on label claims of nutritional adequacy by pet food industries in Pakistan has not yet been validated.

\section{REFERENCES}

1. Akinrinmade F, Akinrinde AS (2011). Nutritional composition and label evaluation of some commercial dry dog foods in Ibadan, Nigeria. Afr. J. Biomed. Res. 14(2): 157-160.

2. Andersen DA, Harpe RL (1990). U.S. Patent No. 4,892,748. Washington, DC: U.S. Patent and Trademark Office.

3. AOAC (1990). Association of Official Analytical Chemists. Official methods of analysis. $15^{\text {th }} \mathrm{Ed}$. Washington, DC.

4. AOAC (2005). Association of Official Analytical Chemists, Official Methods of Analysis, $18^{\text {th }}$ Edition, Washington DC, USA.

5. Begum N, Adil R and Shah FH (1985). Contamination of groundnuts with Aflatoxins, Pak. J. Med. Res. 24: 129-31.

6. Beynen AC (2020). Baked dog food. Erişim adresi: https://www. researchgate.net/publication/340271 675_Beynen_AC_2020_Baked_dog_ foodErişim Tarihi, 3.

7. Bhowmik S, Chowdhury SD, Kabir MH, Ali MA (2008). Chemical composition of some medicinal plant products of indigenous origin, The Bangladesh Veter. 25(1): 32-39.

8. Deuri D, Hazarika M, Gogoi P, Das A, Upadhyay S (2019). Development of high value cheaper pet food (Dog loaf) and its storage stability under vacuum packaging at refrigerated temperature, J. Entomol. Zool. Stud. 7(3): 1430-1433.

9. Kalpna R, Mital K (2011). Vegetable and fruit peels as a novel source of antioxidants. J. Med. Plants Res. 5(1): 63-71.

10. Kulkarni SD (1997). Roasted soy bean in cookies. Influence on product quality. J. Food Sci. Technology 34:503-505.

11. Nisa A, Zahra N, Firdous S, Ejaz N, Hina S (2012). Detection of aflatoxins in various samples of red chili, Pak. J. Sci. Ind. Res. 55:27-29.

12. Obasi NE, Uchechukwu N, Eke-Obia E (2012). Production and evaluation of biscuits from African yam bean (Sphenostylis stenocarpa) and wheat (Triticum aestivum) flours. Food Sci. Qual. Mgt. 7: 5-12. 
13. Romer TR (1976). A screening method for Aflatoxins in mixed feed and other agriculture commodities, J. Assoc. Off. Anal. Chem. 59: 110117.

14. Scaglione F, Gellman G (1988). U.S. Patent No. 4,735,808. Washington, DC: U.S. Patent and Trademark Office.

15. Wolfe K, Wu X, Liu RH (2003). Antioxidant activity of apple peels. J. Agric. Food. Chem. 51(3):609-614.

16. Zahra N, Kalim I, Muhammad KS, Ahmad I (2020). Quality assessment of aflatoxins contamination in red chillies, J. Biotech. Biores. 2(3):1-5.

17. Zahra N, Nisa A, Kalim I, Saeed K, Hina S, Ahmed I (2015). Development, antioxidant activity, physico-chemical and aflatoxin evaluation of herbal brain boosting product, Res. J. Chem. Sci. 5(6): 4649. 